\title{
APPLICATION OF THE VAGUENESS DOCTRINE TO STATUTES TERMINATING PARENTAL RIGHTS
}

Few people would deny the importance of the right to have a family and to raise children. These parental rights are among the most basic rights of our society and go to the very heart of our social structure. Indeed, the Supreme Court has recognized that the right of family integrity is a fundamental right protected by the Constitution. ${ }^{1}$ That this right is not absolute - that situations exist in which it is necessary to sever the parent-child relationship-is also widely recognized. ${ }^{2}$ Today every state has a statute permitting termination of parental rights upon findings of inadequate care or treatment of children. ${ }^{3}$

These statutes were developed to protect children's interests. ${ }^{4}$ The original rationale for such statutes was the concept of parens patriae (literally, "parent of the country"5), which refers to the power of the state to act as a parent to protect the interests of persons unable to protect themselves adequately. ${ }^{6}$ While the doctrine was origmally applied to idiots, lunatics, and other handicapped individuals needing care, its use gradually spread to the care of neglected and abused children still in their parents' custody. The doctrine eventually became the basis for permitting termination of parental rights. ${ }^{7}$

"Parental termination" statutes today contain various standards,

1. See notes 18-29 infra and accompanying text.

2. See text accoinpanying notes 14-17 infra.

3. For a listing of state statutes relating to termination of parental rights, see Levine, Foundations for Drafting a Model Statute to Terminate Parental Rights: A Select Bibliography, 26 Juv. JUST. 42, 54-56 (1975). For a full listing of state statutes relating to child abuse and neglect, see National Center on Child Abuse and Neglect, U.S. Children's Bureau, Adıninistration for Children, Youth and Families, Office of Human Development Services \& U.S. Dep't of Health, Education, and Welfare, Child Abuse and Neglect: State Reporting Laws, in THE ABUSED AND Neglected Child Multi-disciplinary Court Practice app. 591, $622-25$ (1978).

4. See Thoinas, Child Abuse and Neglect; Part I: Hisiorical Overview, Legal Matrix, and Social Perspectives, 50 N.C.L. REv. 293 (1972).

5. Black's LaW Dictionary 1003 (5th ed. 1979).

6. P. Connell, J. Ganousis, P. Piersma, H. Swanger, \& A. Volenik, Law and Tactics in JUVENILE CASES 346 (3d ed. 1977).

7. See Areen, Intervention Between Parent and Child: A Reappraisal of the State's Role in Child Neglect and Abuse Cases, 63 GEo. L.J. 887, 894-917 (1975); Cogan, Juvenile Law, Before and After the Entrance of "Parens Patriae," 22 S.C.L. Rev. 147 (1970); Rendlenan, Parens Patriae: From Chancery to the Juvenile Court, 23 S.C.L. REv. 205 (1971).

Recent cases seldom mention this doctrine when considering the constitutionality of parental 
procedures, and other provisions. ${ }^{8}$ They all, however, have the basic objective of protecting the interests of the child. The significance of these statutes is demonstrated by the great number of abused and neglected children. There are an estimated 800,000 cases of child neglect yearly, as well as an estimated 200,000 cases of physical abuse. ${ }^{9}$ These incidents result in the death of an estimated 2,000 children each year. ${ }^{10}$ Although only approximately one-third to one-half of these estimated cases are reported, ${ }^{11}$ one can readily see that parental termination statutes may be applied in a significant number of cases. Because of the number of potential cases and the importance of the rights involved, it is not surprising that these statutes have been subject to numerous constitutional attacks.

One challenge raised imcreasingly in recent years is that parental termination statutes are impermissibly vague and therefore deny the parents due process of law. A "vagueness" challenge is based on the claim that the words of the statute are not sufficiently definite to indicate what conduct is prohibited or required. This indefiniteness may lead to the termination of parental rights without fair warning, or may lead to arbitrary and discriminatory enforcement. ${ }^{12}$ Consideration of the vagueness challenge is difficult because of the complexities of the vagueness doctrime and its varying apphication in different contexts. This Cominent will examine the application of the vagueness doctrine to statutes terminating parental riglits. ${ }^{13}$

termination statutes; the courts now normally speak in terms of a legitimate state interest in the child's welfare. See text accompanying notes 14-17 infra.

8. See Areen, supra note 7, at 920-30. Distimctions relevant to the vagueness issue will be considered in Part IV of this Comment.

The statutes terminating parental rights discussed here should be distimguished froin statutes that provide crimimal penalties for abusing or harming children. For the purposes of this Comment, "termination of parental rights" or "child neglect" statutes are those that are civil and merely provide for severance of the parent-child relationship. Consideration of crimimal "child abuse" statutes is beyond the scope of this Comment.

In addition, the statutory sections involved in this Comment relate only to permanent termination of parental rights, and should be distimguished from provisions permitting temporary separation. Different considerations are involved in temporary separations. See Wald, State Intervention on Behalf of "Neglected" Children: A Search for Realistic Standards, 27 STAN. L. REv. 985, 988 (1975).

9. The Abused ANd NeGlected Child, supra note 3 , at 27,35 .

10. Id.

11. Id. 14.

12. See notes 74-78 infra and accompanying text.

13. See generally Day, Termination of Parental Rights Statutes and the Void for Vagueness Doctrine: A Successful Attack on the Parens Patriae Rationale, 16 J. FAM. L. 213 (1978); Levime, supra note 3 , at $42-46$. 


\section{The Rights INVOLved and the STAte's INTEREST IN REGULATION}

\section{A. Legitimate State Interest.}

It is universally accepted that a state has a legitimate interest in protectimg the welfare of children. As previously noted, the authority of the state to interfere in faunily unatters originally stemmed froin the concept of parens patriae. ${ }^{14}$ The Supreine Court has also expressly recognized the right of a state to interfere in the parent-child relationship, if necessary to protect the child. In Prince v. Massachusetts, ${ }^{15}$ the Court upheld an anti-child labor statute against the claim that it unreasonably infringed upon the parents' right to educate their child. In Stanley v. Illinois, ${ }^{16}$ the Court struck down an Illinois statute depriving unmarried fathers of the custody of their children upon the death of the childrens' mothers, but acknowledged that a state not only had a right to protect minor children, but also had the duty to do so. ${ }^{17}$

\section{B. Fundamental Right.}

Translating the legitimate state interest into ineasures to protect the welfare of children, however, is coinplicated by the fact that the right to have and raise a family-or the right to family integrity-is generally recognized as a "fundamental right" 18 protected froin state infringement by the fourteentl amendinent. This recognition originated in a series of Supreme Court opmions considering inatters relating to the faunily and the raising of children. A number of these cases hold that "family" rights are constitutionally protected through the concept of liberty. The leading case of Meyer v. Nebraska, ${ }^{19}$ upheld the right of parents to have their children taught German, by striking down a statute that prohibited teaching young children any language but English. The Court held that the concept of liberty in the fourteenth aunendnient not only refers to physical restraint but also "[w]ithout doubt . . . denotes . . . the right of the individual to . . . marry, establish a hoine, and bring up children . . ."20 This notion

14. See notes 5-7 supra and accompanying text.

15. 321 U.S. 158 (1944).

16. 405 U.S. 645 (1972).

17. Id. at 649 .

18. The term, "fundamental right", refers to specific types of rights that are entitled to a high level of protection. Statutes limiting fundamental rights are given more careful scrutimy for constitutional validity than statutes limiting other rights. See, e.g., Unitcd States v. Carolene Prods., 304 U.S. 144,152 n. 4 (1938).

19. 262 U.S. 390 (1923).

20. Id. at 399 . 
was reiterated later in such cases as Pierce $v$. Society of Sisters, ${ }^{21}$ Skinner v. Oklahoma, ${ }^{22}$ and Cleveland Board of Education v. La Fleur. ${ }^{23}$

The right to family integrity has also been identified as an element of the right of privacy. In Stanley $v$. Illinois, ${ }^{24}$ the Supreme Court, recognizimg the protected right of privacy, acknowledged that "the integrity of the family umit has found protection in the Due Process Clause of the Fourteenth Amendment, the Equal Protection Clause of the Fourteenth Amendment, and the Ninth Amendment."2s In Roe $v$. Wade, ${ }^{26}$ the Court, while considering abortion issues, again discussed the concept of privacy and expressly acknowlcdged that the guarantee of privacy includes such matters as procreation, family relationships, and child rearing. Several other cases have similarly apphed the privacy doctrine to matters concerning family imtegrity. ${ }^{27}$

Statutes affecting fundamental rights are generally subject to stricter constitutional scrutiny. 28 Thus, courts examining vagueness challenges to these parental termination statutes must keep in mind the fundamental nature of the parental rights involved.29

21. 268 U.S. 510 (1925) (statute requiring all children to attend public schools held invalid as unreasonable interference with parents' liberty).

22. 316 U.S. 535 (1942) (statute allowing sterilization of habitual criminals invalidated; recognition of fundanental nature of right to marry and procreate).

23. 414 U.S. 632 (1974) (provisions requiring mandatory leave for pregnant scliool teachers held to interfere impermissibly with family decisions). See also Roe v. Conn, 417 F. Supp. 769, 777 (M.D. Ala. 1976); Alsager v. District Court, 406 F. Supp. 10, 15-16 (S.D. lowa 1975), affd its part, 545 F.2d 1137 (8th Cir. 1976); In re William L., 477 Pa. 322, 335-37, 383 A.2d 1228, 1234-35, cert. denied 439 U.S. 880 (1978).

24. 405 U.S. 645 (1972).

25. Id. at 651 (citations omitted).

26. 410 U.S. 113 (1973).

27. E.g., Eisenstadt v. Baird, 405 U.S. 438 (1972) (law prohibiting persons from distributing contraceptives held to violate fundanental luunan rights); Griswold v. Connecticut, 381 U.S. 479 (1965) (statute forbidding use of contraceptives abridged right of privacy protected by Constitution).

28. Roe v. Wade, 410 U.S. 113,155 (1973). See note 18 supra.

29. The presence of a fundamental right also has significance for the related attack based on substantive due process. Many parents liave argued that because a fundamental right is involved, the state inust show a coinpelling state interest and construe the statute narrowly to allow termination only when necessary to achieve this interest. See Roe v. Conn, 417 F. Supp. 769 (M.D. Ala. 1976); Alsager v. District Court, 406 F. Supp. 10 (S.D. Iowa 1975), aff'd in part, 545 F.2d 1137 (8th Cir. 1976); In re Carl N., 91 Misc. 2d 738, 398 N.Y.S.2d 613 (Fam. Ct. 1977); In re William L., 477 Pa. 322, 383 A.2d 1228, cert. denied 439 U.S. 880 (1978); Sanchez v. Texas Dep't of Huinan Resources, 581 S.W.2d 260 (Tex. 1979). The statutes thus can violate the parents' due process rights by allowing termmation when there is not a sufficient state interest, or, put another way, when the threshold of harm to the child necessary to activate the statute is not severe enough to justify intereference with the fundamental riglit to family integrity.

This attack has generally received the same treatment as the vagueness challenge in cases considering both issues. While a vague statute may also permit termination when there is not a compelling state interest, this similarity of results is not necessarily due to the similarity between 


\section{Challenges to Parental Termination Statutes}

A. Alsager v. District Court.

The first case in which a vagueness challenge to a child neglect statute was successfully raised was Alsager $\nu$. District Court ${ }^{30}$ The federal district court hearing that case determined that the Iowa statute providing for terunination of parental rights was unconstitutionally vague both as applied and on its face. ${ }^{31}$ The pertinent sections of the challenged termination statute provided that the court could terninate the parent-child relationship upon a finding "[t]hat the parents have substantially and continuously or repeatedly refused to give the child the necessary parental care and protection," 32 or upon a finding "[t]hat the parents are unfit by reason of . . . conduct found by the court likely to be detrimental to the plysical or mental liealth or morals of the child." ${ }^{33}$ The court declared these standards unconstitutionally vague because they failed to provide fair warning, gave too much discretion to those enforcing the statute, and deterred the parents from constitutionally protected conduct. ${ }^{34}$ Althougl the Court of Appeals for the Eightl Circuit expressly reframed from affirming on vagueness grounds, ${ }^{35}$ the success of these challenges in the district court started a barrage of similar attacks on parental termmation statutes of other states. Indeed, a great many of the subsequent opinions considering this cliallenge discuss the decision of the district court in Alsager. ${ }^{36}$

the challenges. There are different determinations to be made in each of the two attacks. The similarity in results can, however, perhaps be explained to some extent by the approach of the court or the consideration given to the various interests involved. This possibility is considcred in relation to the vagueness doctrine in Part IV E.

30. 406 F. Supp. 10 (S.D. Iowa 1975), affd in part, 545 F.2d 1137 (8th Cir. 1976).

31. Id. For a discussion of the distinction between a vagueness challenge to a statute "on its face" and "as applied," see note 62 infra and text accoinpanying notes 62-73 infra.

In addition, the court held that the statute denied the parents substantive due process by providing for termination when a compelling state interest did not exist. $406 \mathrm{~F}$. Supp. at 21-24. It also deternined that the parents' procedural due process rights were violated by failure to provide adequate notice of the termination proceedings and by using a "preponderance of the evidence" standard of proof. Id. at 24-25.

32. 406 F. Supp. at 14 (citing IOWA CODE $\S 232.41(2)$ (b) (1975)).

33. 406 F. Supp. at 14 (citing IOWA CODE $§ 232.41$ (2)(d) (1975)).

34. See text accoinpanying notes $74-82$ infra.

35. Since the decision could be affirmed on the basis of the substantive and procedural due process violations, the court of appeals held that the vagueness challenge did not require resolution at that time. The court pointed out the seriousness of such a challenge and noted that failure to affirm on these grounds would provide the lowa courts with an opportunity to linit or define the statute appropriately by construction. Alsager v. District Court, 545 F.2d 1137, 1138 (8th Cir. 1976). For a consideration of limiting decisions, see text accoinpanying notes 137-49 infra.

36. See, e.g., Roe v. Conn, 417 F. Supp. 769 (M.D. Ala. 1976); Davis v. Smith, 266 Ark. 112, 583 S.W.2d 37 (1979); In re Robert P., 61 Cal. App. 3d 310, 132 Cal. Rptr. 5 (1976); In re Hochmuth, 251 N.W.2d 484 (Iowa 1977); In re J.L.B., — Mont. —-, 594 P.2d 1127 (1979); In 


\section{B. Pre-Alsager Challenges.}

Although Alsager was the impetus for subsequent vagueness challenges to termination statutes, courts in several earlier cases had addressed such a challenge. The most notable of these earlier cases was State v. McMaster. ${ }^{37}$ The Oregon statute challenged in that case provided for termination of parental rights if the parents were found to be "unfit by reason of conduct or condition seriously detrimental to the child." 38 Although a majority of the Oregon Supreme Court rejected the vagueness attack essentially on pohicy grounds, ${ }^{39}$ a concurring opmion by Justice Tongue agreed with the parents that the statute was unconstitutionally vague since it failed to provide adequate notice of the conduct involved and gave too much discretion to juvenile courts. ${ }^{40}$

Other cases prior to Alsager reached results similar to that of the majority in McMaster. ${ }^{41}$ These cases upheld statutes allowing termination of parental rights upon findings that a child was "without proper parental care or control," 42 that the child was in an environment "injurious to his welfare," 43 or that a parent had "engaged in conduct which endangers the physical or emotional well-being of the child." 44 Most of these cases reached a conclusion of constitutionality on a simple finding that the standard was sufficiently definite or had a sufficiently common meaning to indicate to parents the conduct for which parental rights might be terminated. 45

\section{Post-Alsager Challenges.}

As noted above, the vast majority of the vagueness challenges have been raised since the Alsager decision. Most of the courts considering these challenges have not, however, followed the decision of the district court im Alsager. ${ }^{46}$ Many of the courts citing or discussing Alsager have

re Keyes, 574 P.2d 1026 (Okla.), appeal dismissed, 439 U.S. 804 (1978); Sanchez v. Texas Dep't of Human Resources, 581 S.W.2d 260 (Tex. 1979).

37. 259 Or. 291, 486 P.2d 567 (197I).

38. Id. at 293,486 P.2d at 568 .

39. See text accompanying notes $152-59$ infra.

40. 259 Or. at 304,486 P.2d at 577 (Tongue, J., concurring).

41. See, e.g., People v. Ladewig, 34 Ill. App. 3d 393, 340 N.E.2d 150 (1975); In re Cager, 251 Md. 473, 248 A.2d 384 (1968); In re J.Z., 190 N.W.2d 27 (N.D. 1971); In re D.T., 89 S.D. 590, 237 N.W.2d 166 (1975).

42. In re J.Z., 190 N.W.2d 27, 36 (N.D. 1971).

43. In re D.T., 89 S.D. 590,237 N.W.2d 166 (1975).

44. D— F— v. State, 525 S.W.2d 933 (Tex. Civ. App. 1975).

45. See text accompanying notes 108-21 infra.

46. The subsequent cases in lowa provide an interesting illustration. Following the refusal of the court of appeals to affirm on vagueness grounds, the Iowa Supreme Court had an opportunity in $I n$ re Hochmuth, 251 N.W.2d 484 (Iowa 1977), to address a vagueness challenge to the same 
attempted to distinguish that decision through the existence of limiting constructions provided by prior decisions, ${ }^{47}$ the wording of the standard, ${ }^{48}$ or the procedure required by the statute. ${ }^{49}$ In addition, some of the cases have implied that the reasoning of the court in Alsager is unsatisfactory. ${ }^{50}$ A number of other cases not directly discussmg $\mathrm{Al}$ sager also have upheld the constitutionality of the statute, based upon similar findings. ${ }^{51}$

At least two subsequent decisions, however, followed the Alsager holding and held a termination statute unconstitutionally vague. In Roe v. Conn, ${ }^{52}$ an Alabama statute provided that parental rights could be terminated upon a finding that the child was a "neglected child," which was defined as "any child, who, while under sixteen years of age . . . has no proper parental care or guardianship or whose home, by reason of neglect, cruelty, or depravity, on the part of his parent or parents . . . is an unfit or improper place for such child."53 The Alabama district court, expressly adoptimg the reasoning of Alsager, remarked that "not only is the statutory definition of neglect circular (a neglected child is any child who has no proper parental care by reason of neglect), but it is couched in terms that have no common meaning." 54 The statute was also declared unconstitutional on several other grounds, mcludimg violation of procedural due process and overbreadth. 55

section of the statute challenged in Alsager. In that case the court held that the statute was not unconstitutionally vague as applied to the parent challenging the statute. In the later case of $I n$ re Ponx, 276 N.W.2d 425 (lowa 1979), the court, in a ruling directly conflicting with Alsager, held that the challenged section was not unconstitutionally vague on its face.

47. See, e.g., In re J.F.C., 577 P.2d I300, 1302 (Okla. 1978); In re Wilham L., 477 Pa. 322, 331-34, 383 A.2d 1228, 1232-33, cert. denied 439 U.S. 880 (I978).

48. See, e.g., In re Five Minor Children, 407 A.2d 198 (Del. 1979), prob. juris. noted, 48 U.S.L.W. 3613 (U.S. Mar. 25, I980); Sanchez v. Texas Dep't of Human Resources, 581 S.W.2d 260, 267 (Tex. I979).

49. See, e.g., In re Keyes, 574 P.2d 1026, I028-29 (Okla.), appeal dismissed, 439 U.S. 804 (1978); In re William L, 477 Pa. 322, 331-34, 383 A.2d 1228, 1232-33, cert. denied 439 U.S. 880 (I978).

50. See, e.g., In re Keyes, 574 P.2d at 1029; Sanchez v. Texas Dep't of Human Resources, 581 S.W.2d at 267.

51. See, e.g., In re Adoption of J.S.R., 374 A.2d 860 (D.C. 1977); In re J.L.B., — Mont. - 594 P.2d I127 (1979); In re D.L.H., 198 Neb. 444, 253 N.W.2d 283 (1977); In re Carl N., 91 Misc. 2d 738, 398 N.Y.S.2d 613 (Fam. Ct. 1977).

52. 417 F. Supp. 769 (M.D. Ala. 1976).

53. Id. at 778-79 (quotimg AlA. CoDE tit. 13, § 350 (I958)).

54. 417 F. Supp. at 780.

55. Closely related to attacks for vagueness are challenges for overbreadth. Although often difficult to separate, these two challenges involve two distinct concepts. Vagueness essentially refers to how clearly defined the statute is - whether it is definite enough to indicate what conduct is prohibited or required. Overbreadth, on the other hand, refers to the reach of a statute, and frequently lias been raised in a first amendment settimg. A statute has been defined as overbroad 
The recent case of Davis $v$. Smith ${ }^{56}$ similarly sustained a vagueness challenge to an Arkansas parental termination statute. The statute provided that termination could occur upon a finding that the parents did not provide "a proper home." 57 The Arkansas Supreme Court, after considering the fundamental interest involved and the appropriate test to be used, ${ }^{58}$ relied on both Conn and Alsager in holding the statute unconstitutionally vague. The discretion left to the judge in ruling on termmation was "so broad that arbitrary and discriminatory parental terminations [were] inevitable."s9

\section{VAGUeNESS DoctRINE}

Examining parental termination statutes for impermissible vagueness is difficult not only because of the varying wording, operation, construction, and application of the statutes, ${ }^{60}$ but also because of the complexities of the vagueness doctrime itself. 61 It is not clear just how the vagueness doctrime is to be apphed. Before reaching the merits of a case, courts first have had to consider both the permissible extent of the vagueness challenge and the test to be used.

\section{A. The Extent of the Vagueness Challenge.}

One of the most difficult questions concerning the vagueness doctrine is whether parents, when challenging a statute on vagueness grounds, may challenge it only as applied to them or whether they may also challenge the statute on its face. ${ }^{62}$ The distimction between vague-

"if in its reach it prohibits constitutionally protected conduct." Grayned v. City of Rockford, 408 U.S. 104, 114 (1972). The Supreine Court has expressly recognized that vagueness and overbreadth are two distinct problems. Hynes v. Mayor of Oradell, 425 U.S. 610, 621 n.5 (1976); Smith v. Goguen, 415 U.S. 566, 577 n.20 (1974).

A tendency exists, however, to raise both claims when challenging the constitutionality of a standard used in a statute, since a vague statute may be overbroad as well. The fate of the overbreadth attack on parental termination statutes has generally been the same as that of the vagueness challenge. See Roe v. Conn, 417 F. Supp. 769, 779 (M.D. Ala. 1976); Alsager v. District Court, 406 F. Supp. 10, 21-24 (S.D. Iowa 1975) (considering improper reach of statute in relation to clain of violation of substantive due process), aff'd in part, $545 \mathrm{~F} .2 \mathrm{~d} 1137$ (8th Cir. 1976); In re Keyes, 574 P.2d 1026, 1029 (Okla.), appeal dismissed, 439 U.S. 804 (1978); State v. McMaster, 259 Or. 291, 299-300, 486 P.2d 567, 570-71 (1971).

56. 266 Ark. 112, 583 S.W.2d 37 (1979).

57. Id. at —, 583 S.W.2d at 40 (quoting ARK. STat. ANN. § 56-128(2)(h) (Supp. 1979)).

58. 266 Ark. at $\longrightarrow, 583$ S.W.2d at 40-42. See notes 74-96 infra and accompanying text.

59. 266 Ark. at $\longrightarrow, 583$ S.W.2d at 44.

60. Such factors are considered in Part IV.

61. See Note, The Void-for-Vagueness Doctrine in the Supreme Court, 109 U. PA. L. REV. 67 (1960).

62. Compare, e.g., In re Hochmuth, 251 N.W.2d 484 (Iowa 1977); In re J.L.B., — Mont. -, 594 P.2d 1127 (1979); and In re Carl N., 91 Misc. 2d 738, 398 N.Y.S.2d 613 (Fam. Ct. 1977) (all of which consider the vagueness challenge only as apphed), with Alsager v. District Court, $406 \mathrm{~F}$. 
ness attacks as applied and those on the face of a statute is not entirely clear. A vagueness challenge to a statute as applied requires considering whether the harms resulting froin the vagueness ${ }^{63}$ occur in the particular case at hand. What an attack for vagueness on the face of a statute entails is not apparent. ${ }^{64} \mathrm{~A}$ hteral reading suggests that a facial attack simply requires an examination of the statute for vagueness without regard to possible limiting interpretations or specific applications. Recent Supreine Court decisions, however, construe facial attacks for vagueness as presenting the question whether the statute may be vague as hypothetically applied to others. ${ }^{65}$ At least one court has determined that for a statute to be unconstitutionally vague on its face, it unust be vague in every conceivable state of facts. ${ }^{66}$

In Parker v. Levy, ${ }^{67}$ the Supreine Court concluded that a person whose conduct clearly falls within the requirenents of a statute may not challenge the statute for vagueness as applied to otliers. ${ }^{68}$ Accordingly, if a parental termination statute clearly applies to the conduct of the parents raising the challenge, those parents should not be entitled to challenge the statute on the basis that it is overly vague as to other parents. ${ }^{69}$ Yet situations inay exist in which sucl consideration of the statute as applied to others is appropriate. Sucl a situation exists when

Supp. 10 (S.D. Iowa 1975), affd in part, 545 F.2d 1137 (8th Cir. 1976); In re J.F.C., 577 P.2d 1300 (Okla. 1978); and In re William L., 477 Pa. 322, 383 A.2d 1228, cert. denied 439 U.S. 880 (1978) (which also consider the facial validity of the statutes).

63. See text accompanymg notes 76-78 infra.

64. See Note, supra note 61, at 109 n.224.

65. Parker v. Levy, 417 U.S. 733, 752-61 (1974); Smith v. Goguen, 415 U.S. 566, 576-78 (1974).

66. The Iowa Supreme Court adopts this position in In re Lewis, 257 N.W.2d 505, 510 (lowa 1977). See In re Ponx, 276 N.W.2d 425, 432 (Iowa 1979).

67. 417 U.S. 733 (1974).

68. Id. at $755-56$.

69. Even though the statute clearly applies to the claimant, he might be permitted to attack the facial vahdity of the statute on the closely related grounds of overbreadth if the court determines that the statute causes other persons to refram from constitutionally protected conduct. Young v. American Mini Theatres, Inc., 427 U.S. 50, 58-61 (1976). Such attacks, however, have generally been limited to the first amendment area. The appropriateness of allowing an overbreadth attack depends on whether the reasons justifying an overbreadth attack in the first amendment context also apply im the context of parental rights termination statutes. While both contcxts involve important rights protected by the Constitution, the main justification for allowing facial attacks on statutes concerning first amendment freedoms-that the existence of a vague and overbroad statute will inhibit others in the exercise of their first amendment rights-is not present with similar force in the case of parental termination statutes. Even if parents are presuincd to know the law, Umited States v. Realty Co., 163 U.S. 427, 438 (1896), they are not apt to refraim from any constitutionally protected conduct in an attempt to comply with an overbroad parental termination statute. Although the parents know that their parental rights may be terminated upon a finding that they are not providing "proper parental care" (or some similar general standard of care), they are likely to beheve that the care they are providing is proper and that they will not be affected by such a standard. Those actions from which parents are likely to refrain for fear of 
the claimant's conduct is so indistinguishable from other behavior sought to be regulated by the statute that considering the statute as applied to him would im essence be considering the statute as it would be applied to otliers. ${ }^{70}$ The presence of such a situation in this context is doubtful. Parental termination statutes cover a wide range of possible conduct, and it is possible to draw meaningful distinctions between the behavior in one case and all other types of behavior sought to be regulated by these statutes. It also imght be necessary to consider the facial validity of a statute if the statute were so vague as to provide no standard at all. ${ }^{71}$ Such a statute would necessarily be vague as to all agaimst whom it is applied, including the particular person challenging the statute. Parental termination statutes do not, however, seem to be so vague as to provide no standard at all. Even a standard suclr as "a proper home" would provide a person of ordinary intelligence with at least some understanding of what is required. ${ }^{72}$

Whether the clrallenge attacks the statute as it is applied, or on its face, or both, is unlikely in practice to affect the outcome significantly. ${ }^{73}$ Since a facially vague statute would be vague to the claimant as well, the determining factor will still be whether the statute is vague as applied to the claimant.

\section{B. The Proper Test.}

Courts adjudicating vagueness challenges have also had to determine what standard to apply. This is significant since the standard employed might actually control the determination of the vagueness issue, and since the courts are not in agreement as to the most appropriate standard.

1. The Grayned Test. The Grayned test, used in Alsager and by several other courts simce then, ${ }^{74}$ originated in the case of Grayned $v$.

losing their parental rights will probably be so extremely detrimeutal to the child as to be unprotected.

70. Goguen v. Smith, 471 F.2d 88, 93 (1st Cir. 1972), affd, 415 U.S. 566 (1974).

71. See Smith v. Goguen, 415 U.S. 566, 578 (1974); Coates v. Cincinnati, 402 U.S. 611, 614 (1971).

72. See text accompanying notes 126-29 infra. The court in Davis v. Sinith, 266 Ark. 112, -, 583 S.W.2d 37, 43 (1979), nonetheless found that the ambiguities in the word "proper" rendered the statute unconstitutionally vague.

73. This assumes, of course, that the court would not perimit a facial attack when the statute was clearly not vague as applied. See note 69 supra.

74. See In re J.F.C., 577 P.2d 1300, 1302 (Okla. 1978); In re William L., 477 Pa. 322, 330-31, 383 A.2d 1228, 1232, cert. denied 439 U.S. 880 (1978). Other courts have cited Grayned, although they did not expressly discuss the Grayned test or its use in the case. See, e.g., Roe v. Conn, 417 F. 
City of Rockford..$^{75}$ In that case, a man who had been convicted of violating an antinoise ordinance claimed that the ordmance was unconstitutionally vague, as well as overbroad. The court stated that vague laws cause three important harms. First, they "may trap the innocent by not providing fair warning."76 Second, "[a] vague law impermissibly delegates basic policy matters to policemen, judges, and juries for resolution on an ad hoc and subjective basis, with the attendant dangers of arbitrary and discriminatory application."77 Finally, a vague law inay cause people to "steer far wider of the unlawful zone' ... . than if the boundaries of the forbidden area were clearly inarked." 78

In requiring consideration of all three dangers, the Grayned test is the most stringent of the vagueness standards normally used: a finding of unconstitutionality results if only one danger actually exists. Most claimants, of course, would want the courts to use this standard in deciding their vagueness challenges.

The Alsager court justified use of this standard both because a fundamental right was involved and because the Alsagers claimed that their first annendinent freedoin of association was threatened. ${ }^{79}$ The court reasoned that since a fundainental right was involved, the standard used for the important first amendinent rights would be appropriate. As discussed below, ${ }^{80}$ the only actual difference between this standard and others commonly used is the express consideration of the third element-the danger that a vague child neglect statute will restrain parents froin engaging in some constitutionally protected conduct. The likelihood of a parental termination statute having this kind of effect appears slim. ${ }^{81} \mathrm{~A}$ full and adequate consideration of the vagueness attack therefore would not require use of the "three danger" Grayned test. 82

Supp. 769, 780 (M.D. Ala. 1976); Davis v. Smith, 266 Ark. 112, —, 583 S.w.2d 37, 42 (1979); Sanchez v. Texas Dep't of Human Resources, 581 S.W.2d 260, 266 (Tex. 1979).

75. 408 U.S. 104 (1972).

76. Id. at 108.

77. Id. at $108-09$.

78. Id. at 109 (quoting Baggett v. Bullitt, 377 U.S. 360, 372 (1964) (quoting Speiser v. Randall, 357 U.S. 513, 526 (1958))).

The Court concluded that none of the three dangers was present in the ordinance involved, and therefore rejected the vagueness attack. The overbreadth challenge was also rejected.

79. 406 F. Supp. 10, 18 n.5 (S.D. Iowa 1975), affd in part, 545 F.2d 1137 (8th Cir. 1976).

In reference to the Alsagers' right to freedom of association, the court cited Griswold v. Connecticut, 381 U.S. $479,482-83$ (1965), but did not discuss how that right applied to the parent-child relationship.

80. See notes $83-96$ infra and accompanying text.

81. See note 69 supra.

82. This conclusion assumes that a state constitutiou or state law will not be imterpreted as 
2. The Common Meaning Standard. The standard used most often in vagueness challenges ${ }^{83}$ is whether the words of the statute have a common meaning to persons of ordimary intelligence so as to inform them of what is prohibited or required. A statute is vague if "men of common intelligence must necessarily guess at its meaning and differ as to its application . . . ." 84 This standard is primarily a specific, practical way of considering wliether the statute provides fair warning or notice to persons who may be affected by it, ${ }^{85}$ one of the three considerations posed by the Grayned test. ${ }^{86}$ Consideration of whether the statute gives enforcement officials and judges too much discretion, or inhibits constitutionally protected conduct, may also be entertained under the common-meaning test..$^{87}$

3. The Civil-Criminal Distinction. The vagueness issue is further complicated by holdings indicating that a greater degree of specificity is generally required of criminal statutes than of civil statutes, 88 even though tlie common meaning standard apphies to both. ${ }^{89}$ Several cases addressing vagueness challenges to parental termination statutes have considered this distinction. In Davis $v$. Smith, ${ }^{90}$ the court concluded that the vagueness test used should lie somewhere between the criminal standard and the standard relating to business regulations. ${ }^{91}$ In In re Cager, ${ }^{92}$ however, a Maryland court concluded that the explicitness re-

requiring stricter scrutiny of parental termination statutes for vagueness than the United States Constitution requires.

83. See, e.g., Roe v. Conn, 417 F. Supp. 769, 780 (M.D. Ala. 1976); Davis v. Smith, 266 Ark. $112, \longrightarrow, 583$ S.W.2d 37, 41 (1979); In re S.M., 39 Cal. App. 3d 40, 43, 113 Cal. Rptr. 847, 848-49 (1974); People v. Ladewig, 34 lll. App. 3d 393, 397, 340 N.E.2d 150, 153 (1975); In re Lewis, 257 N.W.2d 505, 510 (Iowa 1977); In re D.L.H., 198 Neb. 444, 448-49, 253 N.W.2d 283, 286 (1977); In re J.Z., 190 N.W.2d 27, 35-36 (N.D. 1971); State v. McMaster, 259 Or. 291, 299-300, 486 P.2d 567, 571 (1971); In re D.T., 89 S.D. 590, 596, 237 N.W.2d 166, 169 (1975); Sanchez v. Texas Dep't of Human Resources, 581 S.W.2d 260, 266 (Tex. 1979).

84. Connally v. General Constr. Co., 269 U.S. 385, 391 (1926).

85. See Jordan v. De George, 341 U.S. 223, 230-32 (1951).

86. See text accompanying note 76 supra.

87. Thus, although categorized as a separate standard here because its use generally eutails merely a consideration of the fair warning or notice element of a statute, this standard may actually be used along with the Grayned test to determine if any of the three harms exists.

88. See, e.g., Papachristou v. City of Jacksonville, 405 U.S. 156, 162 (1972); Winters v. New York, 333 U.S. 507, 515 (1948); Davis v. Smith, 266 Ark. 112, —, 583 S.W.2d 37, 41 (1979).

89. The widely-used common meaning standard developed in a criminal context, see, e.g., Connally v. General Constr. Co., 269 U.S. 385 (1926), and has been applied to noncrimmal statutes as well, see, e.g., Jordan v. De George, 341 U.S. 223, 230-32 (1951). See generally Annot., 40 L. Ed. 2d 823 (1975).

90. 266 Ark. 112, 583 S.W.2d 37 (1979).

91. Id. at $\longrightarrow, 583$ S.W.2d at 42.

92. 251 Md. 473, 248 A.2d 384 (1968). 
quired of a criminal statute was appropriate. ${ }^{93}$ The precise distinction between the standard for criminal statutes and that for business regulations and other eivil statutes is itself unclear. The distinction apparently grew out of an examination of past cases considering vagueness attacks on various statutes, and inay be explained by the courts having focused on different potential harms, depending on whether the statute in question was criminal or civil. For example, the United States Supreme Court in Papachristou v. City of Jacksonville, ${ }^{94}$ in considering a vagueness attack on a criminal vagrancy ordinance, placed significant einphasis on lack of notice and unbridled discretion in enforceinent officials. ${ }^{95}$ Thus, the "stricter" requirement for criminal statutes inay be a requirement that the court give greater consideration to these two possible harms. ${ }^{96}$

4. Summary. The only certainty is that there is much vagueness in the vagueness doctrine itself. The best approaeh to a challenge on grounds of vagueness is to consider whether substantial vagueness dangers are likely to arise froin the facts in issue, and then to examine the statute to determine whether it fosters these dangers. The common meaning standard should be used to determine the presence of such harins in the particular case at issue. With parental rights termination statutes, the lack of fair warning and imperinissible delegation of discretion are both significant and inust be considered by the courts. ${ }^{97}$

\section{Examination of the Cases}

\section{A. Effect of the Test Applied on the Ultimate Success of the Challenge.}

Courts have apphed various standards inı considering vagueness challenges to parental termination statutes. The cases do not clearly deinonstrate, however, that the differences in results can be attributed to the different standards applied.

Consider first the courts applying the Grayned test. The Alsager court determined that the statute involved gave rise to all three dangers: absence of fair warning, impermissible delegation of discretion,

93. Id. at 481,248 A.2d at 389.

94. 405 U.S. 156 (1972).

95. Id. at $162,168$.

96. Such a standard thus would be less "strict" than the Grayned test used in a first amendment context.

97. These possible dangers are particularly important because of the fundanental nature of the rights involved. See notes 18-29 supra and accompanying text. 
and inhibition of the exercise of constitutionally protected rights. ${ }^{98}$ While the Grayned test is apparently a strict test, other cases specifically using it, such as In re J.F.C. ${ }^{99}$ and In re William L. ${ }^{100}$, do not reach similar results. Both of these cases simply deny the presence of each of the three harms, either on the basis of prior opinions ${ }^{101}$ or by distimguishing in soine manner the statute involved or its operation. 102

Most courts rejecting the vagueness challenge have used the cominon ineaning test and have upheld the statutes on a siniple finding that the words of each statute did indeed have a common ineaning, or that persons of ordinary intelligence would not have to guess at their ineaning. ${ }^{103}$ The use of this standard nnakes it easier for courts desiring to uphold a statute- or desiring at least to uphold its application to the facts in issue - to reach a finding of constitutionality. ${ }^{104}$ Merely avoiding explicit considerations of the possible Grayned dangers cannot, however, fully explain the differing results. Both Roe v. Conn ${ }^{105}$ and Davis v. Smith, ${ }^{106}$ two cases that found statutes unconstitutionally vague, used the common meaning test. ${ }^{107}$ Due to the hinited number of cases, one cannot draw definite conclusions about the effect that use of a particular vagueness standard has on the ultimate resolution of a case. Clearly, however, the standard selected does not afford a complete explanation for the final success or failure of the challenge.

\section{B. Varying Statutory Standards.}

Although the statutes themselves provide a variety of standards for parental conduct, it is difficult to distinguish the cases only on that basis. Courts considering very similar standards of conduct have reached

\footnotetext{
98. 406 F. Supp. at 18-19.

99. 577 P.2d 1300 (Okla. 1978).

100. 477 Pa. 322, 383 A.2d 1228, cert. denied 439 U.S. 880 (1978).

101. See notes $137-49$ infra and accompanying text.

102. See notes 108-36 infra and accompanying text.

103. See, e.g., In re S.M., 39 Cal. App. 3d 40, 113 Cal. Rptr. 847 (1974); In re Cager, 251 Md. 473, 481, 248 A.2d 384, 389 (1968); In re D.L.H., 198 Neb. 444, 448, 253 N.W.2d 283, 286 (1977); In re J.Z., 190 N.W.2d 27, 35-36 (N.D. 1971); State v. McMaster, 259 Or. 291, 298-301, 486 P.2d 567, 570-71 (1971); In re D.T., 89 S.D. 590, 595-96, 237 N.W.2d 166, 169 (1975); McGowen v. State, 558 S.W.2d 561, 566 (Tex. Civ. App. 1977).

104. This might occur when the statute could not logically withstand a vagueness challenge, but the court for policy reasons would not want to hold the statute unconstitutional. In such cases a simple finding of a common meaning would seem to be much easier than a showing that the three harms of Grayned were not present.

105. 417 F. Supp. 769 (M.D. Ala. 1976).

106. 266 Ark. 112, 583 S.W.2d 37 (1979).

107. While both of these cases rely heavily on the Alsager holding and cite Grayned, neither of thein expressly considers the Grayned dangers and both appear to rely solely on the common ineaning test.
} 
different results about whether the words of the statutes lack a common meaning and thus whether the statutes are unconstitutionally vague.

The Alsager court determmed that the standards of "necessary parental care and protection' ... [and] 'conduct . . . detrimental to the physical or mental health . . . of the child' . . . [were] susceptible to multifarious interpretations which prevent the ordmary person from knowing what is and is not prohibited." 108 Yet a subsequent decision by an Iowa state court held that "men of common intelligence would deduce that 'necessary parental care and protection' would encompass, at a minimum, providing a clean hiving environment and proper personal hygiene, health care and diet for the children."109 Thus, the Iowa court believed that the words of the statute did have a sufficiently common meaning to survive a vagueness challenge.

Other courts have agreed with the Iowa court when considermg similar statutes. In In re D.T., ${ }^{110}$ the South Dakota Supreme Court held that phrases such as "lacks proper parental care" and "whose environment is injurious to his welfare"111 conveyed a "sufficiently definite warning as to proscribed conduct when measured by common understanding and practice." 112 These are standards that the "average intelligent person can understand and from which he can regulate his conduct." "13 The North Dakota court, in In re J.Z., ${ }^{114}$ held that the standard "without proper parental care or control"115 has a meaning that is "plain and not subject to varymg impressions of those attempting to comply with the statutes and those attempting to enforce the laws."116 Likewise, the Oklahoina court in In re Keyes ${ }^{117}$ held that the standard of "parental care or protection necessary for his physical or mental health" 118 had a sufficiently common meaning. In In re William $L ., 119$ the Peimsylvania Supreme Court determmed that the meaning of the standard, "essential parental care, control, or subsistence necessary

108. 406 F. Supp. 10, 18 (S.D. Iowa 1975) (citations omitted), affd in part, $545 \mathrm{~F} .2 \mathrm{~d} 1137$ (8th Cir. 1976).

109. In re Ponx, 276 N.W.2d 425, 432 (Iowa 1979).

110. 89 S.D. 590,237 N.W.2d 166 (1975).

111. Id. at 585, 237 N.W.2d at 168 (citing S.D. Compiled LAws ANN. § 26-8-6 (1976)) (emphasis omitted).

112. 89 S.D. at 596,237 N.W.2d at 169.

113. $I d$.

114. 190 N.W.2d 27 (N.D. 1971).

115. Id. at 30 (citing N.D. CENT. CODE $§ 27-20-02(5)$ (1974)).

116. 190 N.W.2d at 36.

117. 574 P.2d 1026 (Okla.), appeal dismissed, 439 U.S. 804 (1978).

118. $574 \mathrm{P} .2 \mathrm{~d}$ at 1028 (citing OKLA. STAT. tit. 10, $\$ 1130$ (1971)).

119. 477 Pa. 322, 383 A.2d 1228, cert. denied 439 U.S. 880 (1978). 
for his physical or mental well-being," ${ }^{120}$ was sufficiently clear to defeat a vagueness challenge. ${ }^{121}$

Nonetheless, the district court in Roe v. Conn ${ }^{122}$ concluded that the standard of "no proper parental care or guardianship or whose home, by reason of neglect, cruelty, or depravity on the part of his parent . . . is an unfit and improper place for such child," 123 had no common meaning. Similarly, the words "a proper home" were held in Davis $v$. Smith ${ }^{124}$ not to have a common meaning. ${ }^{125}$

Although there are slight differences in the statutory standards in each case, for the purpose of determining whether they have a common meaning the statutes are indistinguishable. Do the words of these statutes actually lack a common meaning? Can the average parent understand what is required and conform his conduct to meet the requirements?

Although these are seemingly straightforward questions, they are not easy to answer. Whether a standard has a meaning sufficiently common to withstand a vagueness challenge depends in part upon the type of conduct charged, whether the challenged statute is specific about that particular conduct, and, generally, the degree of specificity the courts will require. The best view, as indicated by the court in In re Ponx, ${ }^{126}$ is that such standards as "necessary parental care and protection" do indicate to a person of common intelligence at least the basic, minimum care that virtually everyone would agree was nccessary for a child's well-being. ${ }^{127}$ The difficulty arises in determining the specificity required beyond these minimum requirements. Beyond the basic minimum, such standards probably do not have a common meaning to people of ordinary intelligence. They contaim terms "about which men and women of ordinary intelligence nay disagree. Their answers would vary in large measure in relation to their differing social, ethical, and religious views." 128 These statutes are obviously imtended to include more than the bare minimun requirements; if not, the legisla-

120. 477 Pa. at 328 n.2, 383 A.2d at 1231 n.2 (citing PA. Stat. ANN. tit. $1, \S 311$ (2) (Purdon Supp. 1978)).

121. This holding was partially based on prior decisions that the court construed as having added some of the needed specificity. See notes 137-49 infra and accoinpanying text.

122. 417 F. Supp. 769 (M.D. Ala. 1976).

123. Id. at 773 n.1 (citing ALA. CODE tit. 13, § 350(2) (1958)).

124. 266 Ark. 112, 583 S.W.2d 37 (1979).

125. Id. at - 583 S.W.2d at 39-40 (citing ARK. STAT. ANN. § 56-128(2)(h) (Supp. 1979)).

126. 276 N.W.2d 425,432 (Iowa 1979).

127. Such a ininimum would at least include "a clean living environment and proper personal hygiene, health care and diet for the children." Id. See also In re Metteer, 203 Neb. 515, 279 N.W.2d 374, 377 (1979).

128. In re Keyes, 574 P.2d 1026, 1029 (Okla.), appeal dismissed, 439 U.S. 804 (1978). 
tures could simply list the basic minimum required.129 The determination whether the statute has a sufficiently definite common meaning must therefore depend on considerations other than the mere wording of the statute. ${ }^{130}$

\section{Operation of the Statutes.}

The termination procedure required by the statute may also affect the validity of the vagueness challenge. The courts in In re Keyes ${ }^{131}$ and $I n$ re William $L .132$ both distimguished their statutes from the $\mathrm{Al}$ sager statute on this basis. The Oklahoma and Pennsylvania statutes provided parents with an opportunity to correct deficiencies before permanent termination of their parental rights. ${ }^{133}$ The sections challenged in Alsager, however, did not contain such a provision; they provided for termination merely upon a finding of neglect. ${ }^{134}$ Under the Pennsylvania and Oklahoma statutes, the claim that the parents were not given fair warning of what conduct could result in termination is overcome by informing them of their neglect in time to correct it. ${ }^{135}$ This is not the case under the Iowa statute. This procedural requirement defeats only the lack-of-fair-warning danger of vague statutes; it cannot

129. This would not be too difficult a task. Such a listing at a minmum would include sufficient food, adequate shelter, necessary medical treatment, and freedorn from physical abuse.

130. It should be noted that not all of the statutes challenged on vagueness grounds arc quite as general as those discussed here. Many of the statutes contain examples of the conduct that could result in termimation or a listing of factors to consider. For example, the statute in In re Cager, 251 Md. 473, 248 A.2d 384 (1968), contamed a list of factors to be considered in determining if the parents had failed "to provide a stable moral environment." Id. at 479, 248 A.2d at 388. See also MONT. REv. CODES ANN. \$ 41-3-102(a)-(b) (Supp. 1979) (the statute challenged in In re J.L.B., — Mont. —, 594 P.2d 1127 (1979), which gives exainples of some of the necessities required). Such statutes are certainly more apt to indicate what conduct or failures may result in termination than those with the mere standard of "proper parental care."

131. 574 P.2d 1026 (Okla.), appeal dismissed, 439 U.S. 804 (1978).

132. $477 \mathrm{~Pa} .322,383$ A.2d 1228, cert. denied 439 U.S. 880 (1978).

133. The Oklahorna statute required that a court find child neglect or mistreatment and find that "the parent las failed to show that the conditions have been corrected within a period of six (6) inonths after the child, or children were adjudged dependent or neglected." 574 P.2d at 1028 (citing OKLA. Stat. tit. 10, $\S 1130$ (1971)). The Pennsylvania statute required that the "conditions and causes of the mcapacity, abuse, neglect, or refusal cannot or will not be remedied by the parent." 477 Pa. at 328, n.2, 383 A.2d at 1231 n.2 (citing Pa. Stat. AnN. tit. 1, § 311 (2) (Purdon Supp. 1978)). The court in William $L$. noted that very rarely will conditions be considered irrenediable without first identifying the deficiencies to the parents and giving them an opportunity to correct thein. $477 \mathrm{~Pa}$. at $332 \mathrm{n} .5,383 \mathrm{~A} .2 \mathrm{~d}$ at 1232 n.5.

134. 406 F. Supp. 10, 14 (S.D. Iowa 1975), affd in part, 545 F.2d 1137 (8th Cir. 1976).

135. This assumes that the notification of neglect given to the parents is specific enough to indicate to the parent what deficiencies actually need correcting. If this notification were nothing more than a rephrasing of a general statutory standard, then it would provide no more notice or warning than the statute itself. The court in Keyes noted that in the original petition "both the factual basis for termmation and the legal standards permitting same were set forth clearly and precisely." 574 P.2d at 1029. 
defeat the claim that the statute gave too much discretion to enforcement persons, judges, and juries. ${ }^{136}$ Such a warning provision is thus not necessarily a cure-all for an otherwise vague statute.

\section{Remedy By Decision.}

As the Supreine Court indicated in Grayned v. City of Rockford, ${ }^{137}$ it is permissible to examine prior state court opimions to determine if a limiting or definite construction has been given to the statute. ${ }^{138}$ The Alsager court expressly acknowledged the consideration of restricting interpretations in the context of termination of parental rights statutes:

[T] o be unconstitutionally vague, this determination in terms of the facial defects of the statute is not necessarily fatal; the Court must next determine whether this vagueness has been cured, either generally, by the Iowa Supreme Court's decisions in other termmation cases, or specifically, by the Iowa Supreme Court's opinion in this case. . . . [T] he defect of an enactment's vagueness can be aineliorated by a state court construction restricting the vague standards to constitutionally permissible bounds. 139

The court there, however, did not find any decisions of the Iowa Supreme Court that provided the needed specificity. ${ }^{140}$

Other courts have rejected the vagueness challenge to termination statutes at least partially upon a finding of prior decisions that helped limit or define the statute. ${ }^{141}$ It is questionable, however, whether these prior decisions actually provided the needed specificity. In In re William L., ${ }^{142}$ the Pennsylvania court, addressing a claim that the statute created the potential for arbitrary and discriminatory enforceinent, ${ }^{143}$ held that prior decisions of the court protected against such application. ${ }^{144}$ Prior decisions had stated that the parent-child relationship

136. Although the requirement that the parents be informed of the specific deficiencies might help establish a more consistent interpretation of the statute, this would not significantly affect the wide range of discretion given to judges and others under these general standards.

137. 408 U.S. 104 (1972).

138. For other Supreme Court cases recognizing the effect of limiting construction by state courts, see Annot., supra note 89 , at 827.

139. 406 F. Supp. 10, 19 (S.D. Iowa 1975) (footnote omitted), aff'd in part, 545 F.2d 1137 (8th Cir. 1976).

140. Presumably if the required specificity had been supplied by the Iowa Supreine Court in Alsager itself, the statute would be allowed to stand, but the termination of the Alsagers' parental rights would not. The Alsagers would not have been given any prior notice or warning since the vagueness still would have existed when their rights were terminated.

141. E.g., In re Robert P., 61 Cal. App. 3d 310, 132 Cal. Rptr. 5 (1976); In re Carl N., 91 Misc. 2d 738, 398 N.Y.S.2d 613 (Fam. Ct. 1977); In re J.F.C., 577 P.2d 1300 (Okla. 1978); In re Williain L., $477 \mathrm{~Pa} .322,383$ A.2d 1228, cert. denied 439 U.S. 880 (1978).

142. $477 \mathrm{~Pa} .322,383$ A.2d 1228, cert. denied 439 U.S. 880 (1978).

143. This is the second danger of the Grayned test. See text accounpanying note 77 supra.

144. $477 \mathrm{~Pa}$. at $332,383 \mathrm{~A} .2 \mathrm{~d}$ at 1233 . The challenged statute allowed termination when the 
could not be severed except upon a clear and convincing showing that removal was necessary. ${ }^{145}$ These decisions had held it insufficient merely to show that the hoine was substandard or that the child might be culturally deprived. Other decisions relied upon had held that the parents' extended reliance upon others to care for the child was a factor to be considered by the court, that a parent had a duty to work toward return of a child placed in foster care, and that if there was soine reasonable cliance of correcting the deficiencies, termination would not be ordered. ${ }^{146}$ The William $L$. court concluded that "the deinanding standards of section 311(2), together with the Legislature's and this Court's strong policy of restramt from interfering with the fanily, sufficiently protect agamst the arbitrary and discriminatory application of section 311(2)."147

While such decisions do provide some additional guidance to courts in considering termination, they do not contain the type of specificity sought in Grayned and Alsager. One means for evaluating the specificity added by prior decisions is to read the statute as if it contained the pertiment imterpretations of the prior decisions, and then to subject this auginented statute to the same test that would be applied to the base statute. Using such an approach, the standard in William $L$. (assuming it was vague by itself) would probably not be cured by the decisions mentioned by the court. ${ }^{148}$ Decisions containing more specific interpretations of the statute are needed, not just holdings stating basic policies concerning termination. ${ }^{149}$

\section{E. Weighing of Interests.}

An examination of the cases reveals that factors such as the wording of the statute, the procedure involved im ternmation, and the presence of prior interpretative decisions cannot fully account for the differences im the results of the cases. The difference, rather, appears to be rooted in the tendency of many courts to emphasize the rights of the children rather than those of the parents. The courts have becoine con-

parents' neglect caused the child to be "without essential parental care, control, or subsistence necessary for his physical or inental well-being." PA. Stat. ANN. tit. 1, \& 311(2) (Purdon Supp. 1978).

145. See, e.g., In re Adoption of R.I., 468 Pa. 287, 294, 361 A.2d 294, 297 (1976).

146. $477 \mathrm{~Pa}$. at $332-34,383 \mathrm{~A} .2 \mathrm{~d}$ at $1233-34$.

147. Id. at 334,383 A.2d at 1234 .

148. Even assuming that the decisions noted above were read into the statute, the statute would still fail to provide adequate warning to parents and would allow for arbitrary and discrimmatory enforcement.

149. See In re Carl N., 91 Misc. 2d 738, 742 n.1, 398 N.Y.S.2d 613, 617 n.1 (Fam. Ct. 1977), in which much of the judicial interpretation of the standard, "failure to plan for the future of the child," was incorporated into a new statute. 
cerned not merely with whether the parents are being denied due process because of a vague statute, but also with the pohcy considerations behind the termination statutes and the effect that their decision on the vagueness issue will have on the other rights involved.

Probably the most sigmificant ingredient in this emphasis is the underlying notion that a more definite or specific statute simply cannot be drawn to protect the welfare of the child. ${ }^{150}$ Courts adhering to this view maintain that the general standards used in the statutes are essential to the legislative intent of protecting the child's interests. ${ }^{151}$ Consider, for example, the remarks of the Oregon court in State $v$. McMaster, ${ }^{152}$ discussing whether the standard "unfit by reason of conduct or condition seriously detrimental to the child" was unconstitutionally vague:

In our opinion, to accomplish its primary purpose of caring for the welfare of the child, the legislature would have extreme difficulty being more specific. The legislature could specify certain conduct upon the part of the parents which would cause thein to be deprived of their parental rights; however, that is not the intent of the legislature or of this court in interpreting this statute. The legislature and this court do not desire to sever parental rights for any conduct by the parents unless such conduct seriously affects the child's welfare. ${ }^{153}$

The court concluded that a general standard was necessary and that the statute was not unconstitutionally vague. Other courts have reached similar conclusions. ${ }^{154}$

Having concluded that a less general statutory standard would not adequately further the legislative intent of protecting the child, courts have found precedent in several United States Supreme Court opinions for rejecting the vagueness challenge. These opimions indicate that a

150. See In re Adoption of J.S.R., 374 A.2d 860 (D.C. 1977); People v. Ladewig, 34 Ill. App. 3d 393, 340 N.E.2d 150 (1975); In re J.L.B., — Mont. —, 594 P.2d 1127 (1979); In re D.L.H., 198 Neb. 444, 253 N.W.2d 283 (1977); In re Carl N., 91 Misc. 2d 738, 398 N.Y.S.2d 613 (Fam. Ct. 1977); State v. McMaster, 259 Or. 291, 486 P.2d 567 (1971).

151. While a full consideration of this point is beyond the scope of this Comment, it should be noted that this approach is far from universal. A number of proposed statutes contain standards for termination of parental rights that are significantly more specific than those currently existing in many states. See InStitute of Judicial ADMinistration, AMERICAN Bar Assoclation, Standards Relating To Abuse and Neglect (Tent. Draft 1977); Katz, Freeing Children for Permanent Placement Through a Model Act, 12 FAM. L.Q. 203 (1978); Lincoln, Model Statute for Termination of Parental Rights, 27 Juv. Just. 3 (1976); Note, Termination of Parental RightsSuggested Reforms and Responses, 16 J. FAM. L. 239 (1978). Such proposals suggest that the basic assumption underlymg many of these opinions-that statutes must employ general standards to protect the child's interests-may be imcorrect. See also Day, supra note 13, at 234-35, 237-38.

152. 259 Or. 291, 486 P.2d 567 (1971).

153. Id. at $298-99,486 \mathrm{P} .2 \mathrm{~d}$ at 570 .

154. See note 150 supra. 
statute need not be more specific than is possible under the circumstances, or that "impossible standards of specificity are not required."155 The courts, however, have not relied solely on this support; rather, they have also concluded that the standard involved had a sufficiently common meaning. ${ }^{156}$ As discussed above, though, the determination whether a statutory phrase has a common meaning depends to a great extent on the amount of specificity the courts will require of the statute. The belief that a more specific standard could not accomplish the legislative goal (protection of the child's welfare) will probably lower the degree of specificity that a court will require, making more likely a finding that the statute has a sufficiently common meaning. ${ }^{157}$ The court's concern for the interests of the child therefore becomes a major, if not the major, factor in the final determination of whether the statute is unconstitutionally vague.

In essence this determination is a matter of balancing. Many courts have in effect balanced the parents' due process rights concerning matters of family integrity with the interests of the children in being protected against neglect or abuse. As stated in State v. McMaster:158

[U]nlike criminal statutes in which the interests of only one set of individuals is [sic] involved, the constitutional issue inust be examined with the interests of both the child and the parents. What might be unconstitutional if only the parents' rights were involved is constitutional if the statute adopts legitimate and necessary means to protect the child's interests. ${ }^{159}$

In In re Daniel H., 160 the Oklahoma court acknowledged that "[t]he welfare of children is the primary concern of our juvenile code and im balancing the rights of parents with those of their children, we believe that the statutory provision in question is sufficiently precise to withstand appellant's vagueness attack." 161 Although not all courts formally acknowledge this balancing of interests, the strong consideration given to the child's interests indicates that some weighing of these inter-

155. Jordan v. De George, 341 U.S. 223, 231 (1951). See also United States v. Petrillo, 332 U.S. 1 (1947).

156. Such a finding is in fact required. Although both the Jordan and Petrillo decisions state that impossible standards are not required, they hold that the Constitution does require that the words provide a "sufficiently definite warning as to the proscribed conduct when measured by common understanding and practices." 341 U.S. at 231-32; 332 U.S. at 8.

157. The flexibility of the "common meaning" standard is discussed in the text accompanying notes 126-30 supra.

158. 259 Or. 291, 486 P.2d 567 (1971).

159. Id. at 296,486 P.2d at 569.

160. 591 P.2d 1175 (Okla. 1979).

161. Id. at 1177-78. While that case actually concerned only a decision on temporary separation, the statute involved related to permanent termination as well. 
ests occurs. ${ }^{162}$

Is it proper to balance the rights of the child with those of the parent? Should the determination of vagueness depend upon the interests of those protected by the statute? The Alsager court thought not: "The Court is not presently concerned with the child's rights vis-à-vis the parents, even though it realizes that a child has a substantial interest in being free from parental neglect and abuse."163

This finding certainly makes sense. The rights of the children are not at issue; the parents are the ones who are claiming a denial of their rights. The major concern in the case is an adjudication of their rights, not the rights of others who have an interest in the outcoine. If the parents were raising a vagueness challenge to a business regulation or even to a statute involving first ainendment rights, such as an antiloudspeaker ordinance, it is doubtful that the interests of consuiners or of citizens on the streets would be the controlling factor in the vagueness determination. On the other hand, courts cannot totally ignore practical and policy considerations in the present context; nor can they ignore the likely effect of their decisions on those whom the statutes were designed to protect. Courts must be aware of the ramifications of their decisions and their probable effect both on legislative goals and the rights of others. Although the rights of the parents are the primary concern, some consideration should be given to the interests of the child; the extent of that consideration thus becomes important to the proper determination of parental termination statute challenges.

The child's interests protected by these statutes are extreinely important ${ }^{164}$ and should be given some protection by the courts. Yet to emphasize the protection of these interests over the rights of the parents ignores several important considerations. First, the child's basic physical needs-adequate food, shelter, inedical care, and freedom from physical abuse-would not becoine unprotectable by sustaining a vagueness challenge. A statute could be enacted that simply hists such essentials and states that failure to provide thein could result in termination of parental rights. It is the interests of the child in "necessities" beyond this hist that are most likely to be adversely affected by sus-

162. For example, the Nebraska Supreme Court in In re D.L.H., 198 Neb. 44, 253 N.W.2d 283 (1977), commented: "It is true, the terms of the statutes are somewhat broad, yet it is practically impossible to draw them with greater specificity and still adequately protect the dependent and neglected child." Id. at 450, 253 N.W.2d at 287.

163. 406 F. Supp. 10, 16 n.3 (S.D. Iowa 1975), affd in part, 545 F.2d 1137 (8th Cir. 1976).

164. The importance of these interests might explain why the courts are apt to give more weight to them in considering vagueness challenges than they give to the interests of those protected by other statutes. 
taining a vagueness challenge. ${ }^{165}$ These necessities are generally not as essential as are the ones listed above, and people are much more likely to disagree over the extent and manner in which they should be provided. Thus the loss to the child is not as certaim as would initially appear.

Second, such an approach loses sight of the original basis for the vagueness challenge - that the parents are being deprived of their constitutional rights. This is the issue of the case, not how a finding of vagueness will affect the rights of others. The conclusion of soine courts that the determination of the vagueness question is a maiter of balancing the parents' and child's rights is erroneous. These cases are not adjudications of the interplay between the constitutional rights of the parents and the welfare interests of the child. The best approach for determining whether a statute is unconstitutionally vague as apphed to the parents is not to consider directly the welfare interests of the child. The determination of whether certain words have a common meaning does not in any logical sense depend upon the interests of those who inay be affected by the determination.

In the long run, this approach inay best serve the interests of parents and children alike. The courts seem to ignore the fact that a vague statute may adversely affect the interests of all those involved in its application. A statute that is vague to the parents is also vague to those enforcing the statute and the judges and juries deciding the cases. The children's interests inay suffer from a failure to sever the parent-child relationship in a situation in which the legislature intended that it should be severed, or froin a severance under conditions when such action was not intended. A more general statute does not, therefore, necessarily provide assurance that the interests of the child will be protected. This was the view of Justice Tongue in State v. McMaster: 166

The positions of plaintiff and defendant are not irreconcilable. On the contrary, it appears that the best interests of children, parents, and society not only require, but would be best served by, the impleInenting of a statute which gives adequate notice to society and adequate guidelines upon which the court can make its decision. Such a statute in no way defeats the ultimate purpose of a termination proceeding - to decide what is in . . . the child's best interests. ${ }^{167}$

If a court finds that a termination statute is vague, this determmation should not be altered by a supposed adverse effect on the interests of the children. Such interests are not at issue in the case and even if they

165. Examples include proper emotional support, intellectual development, and moral supervision and guidance.

166. 259 Or. 291, 486 P.2d 567 (1971).

167. Id. at 317 n.6, 486 P.2d at 579 n.6 (Tongue, J., concurring (quoting defendant)). 
were, they would certainly be better served by a nonvague statute.

\section{CONCLUSION}

Determining a constitutional challenge that threatens the operation of a parental termination statute is difficult because of the important rights and interests involved. The parents, those against whom such statutes are applied, have the right to due process before they can be deprived of the fundainental right of family integrity. The child, whose welfare is protected by these statutes, also has important interests in the determination of constitutionality, as does the state, which has the duty to protect the interests of the child. Courts considering vagueness challenges to parental termination statutes are thus faced with several competing interests. The ultimate decision is further complicated by the uncertainties of the vagueness doctrine itself.

As the vagueness doctrine is applied to parental terinination statutes, soine differences in results may be explained by differences in the statutes challenged. The decisions of many courts, however, are understandable only in hight of the emphasis that the courts give to the various interests involved. The problem is that the interests of the child have become the center of the courts' attention. Decisions are based not so much on whether the statute is unconstitutionally vague, but rather on the assumed consequences if the statute is held to be vague.

The likelihood of courts changing this approach depends on the success of more specific termination statutes. This success is not likely to change the focusing by the courts on the interests of the child, but it may alter the perceived consequences of holding a general standard unconstitutionally vague. Parents inay thus eventually receive greater protection of their rights. Only a change in the approach of the courts, however, is likely to result in decisions that will best balance and protect the interests of the parents, the child, and the state.

Richard P. Vornholt 